\title{
Forest management to increase carbon sequestration in boreal Pinus sylvestris forests
}

\author{
Karolina Jörgensen (D) Gustaf Granath $\mathbb{D}$. \\ Björn D. Lindahl (D) Joachim Strengbom 10
}

Received: 8 April 2021 / Accepted: 4 June 2021 / Published online: 19 June 2021

(C) The Author(s) 2021

\begin{abstract}
Background and aims Forest management towards increased carbon (C) sequestration has repeatedly been suggested as a "natural climate solution". We evaluated the potential of altered management to increase $\mathrm{C}$ sequestration in boreal Pinus sylvestris forest plantations.

Methods At 29 forest sites, distributed along a $1300 \mathrm{~km}$ latitudinal gradient in Sweden, we studied interactive effects of fertilization and thinning on accumulation of $\mathrm{C}$ in standing biomass and the organic horizon over a 40 year period.

Results Abstention from thinning increased the total $\mathrm{C}$ stock by $50 \%$ on average. The increase was significant (14\% on average) even when $\mathrm{C}$ in the removed timber was included in the total ecosystem $\mathrm{C}$ pool.
\end{abstract}

Responsible Editor: Timothy J. Fahey.

K. Jörgensen $(\bowtie) \cdot$ B. D. Lindahl

Department of Soil and Environment, Swedish University

of Agricultural Sciences, Box 7014, 75007 Uppsala,

Sweden

e-mail: karolina.jorgensen@slu.se

G. Granath

Department of Ecology and Genetics, Uppsala University,

Norbyvägen 18D, SE-752 36 Uppsala, Sweden

J. Strengbom

Department of Ecology, Swedish University

of Agricultural Sciences, Box 7044, 75007 Uppsala,

Sweden
Fertilization of thinned stands increased stocks similarly regardless of including (11\%) or excluding (12\%) removed biomass, and fertilization combined with abstention from thinning had a synergistic effect on $\mathrm{C}$ stocks that generated an increase of $79 \%$ (35\% when removed timber was included in the $\mathrm{C}$ stock). A positive effect of fertilization on $\mathrm{C}$ stocks was observed along the entire gradient but was greater in relative terms at high latitudes. Fertilization also reduced soil respiration rates.

Conclusion Taken together, our results suggest that changed forest management practices have major potential to increase the $\mathrm{C}$ sink of boreal forests. Although promising, these benefits should be evaluated against the undesired effects that such management can have on economic revenue, timber quality, biodiversity and delivery of other ecosystem services.

Keywords Forestry · Fertilization · Thinning · Climate mitigation $\cdot$ Latitudinal gradient $\cdot$ Nitrogen

\section{Introduction}

The goal of net zero emissions of carbon dioxide $\left(\mathrm{CO}_{2}\right)$ by 2055 calls for drastically decreased emissions of greenhouse gasses, but also measures that increase removal of carbon (C) from the atmosphere (IPCC 2018). Forests are important global C sinks that annually sequester an estimated $2.4 \mathrm{Gt}$ of $\mathrm{C}$ from the atmosphere (Pan et al. 2011), and thereby pivotal 
components of "natural climate solutions" (Canadell and Raupach 2008; Griscom et al. 2017). Recently, global afforestation to counter historical deforestation has been promoted as a possible means to mitigate climate change (Bastin et al. 2019), but mitigation can also be achieved by changed silvicultural practices (Canadell and Raupach 2008; Griscom et al. 2017). Since the capacity of forests to bind C is linked to stand dynamics and soil fertility, which can both be manipulated by directed management (Magnani et al. 2007; Tamm 1991), optimization of forest management towards increased $\mathrm{C}$ sequestration might be an important measure to reach net zero emissions within the next couple of decades.

The boreal forest is one of the largest terrestrial biomes, and about two thirds of the area is managed in some way (Gauthier et al. 2015). Young, actively growing trees in plantations have a major potential to store $\mathrm{C}$ in newly formed wood (Bastin et al. 2019). In addition, a combination of low temperature, recalcitrant litter and competitive inhibition of decomposers leads to accumulation of a purely organic O-horizon clearly separated from, and overlying, the mineral soil (hereafter: organic horizon) (Berg and McClaugherty 2014; Steidinger et al. 2019; Tamm 1991).The organic horizon, which is characteristic of boreal forests and sometimes referred to as the "mor layer", consist of both litter- and root-derived $\mathrm{C}$ (Clemmensen et al. 2013) and constitutes a significant store of C (Pan et al. 2011; DeLuca and Boisvenue 2012). The $C$ stock of the organic horizon is relatively dynamic and possible to manipulate into increased $\mathrm{C}$ sequestration within decades (Moldan et al. 2006), whereas the around two thirds of the total soil organic $\mathrm{C}$ (SOC) that is stored in the mineral soil (Nilsson et al. 2017) are relatively stable (Rumpel et al. 2002; Schulze et al. 2009).

Most forests in Fennoscandia are intensely managed for biomass production, and thinning is a commonly used practice to improve timber quality and increase economical revenue during a forestry rotation period (Royal Swedish Academy of Agriculture and Forestry 2015). In essence, thinning shifts stand structure from many trees with low individual biomass towards fewer but larger trees by reducing competition and should not, at least theoretically, have a major effect on long-term $\mathrm{C}$ accumulation. This process occurs also without active management, as outcompeted trees die (i.e. self-thinning), but to a lesser extent than during active thinning operations (Westoby 1984). Nevertheless, thinning always has momentary negative effects on the standing biomass, and commonly results in lower standing biomass compared to when forests are left for self-thinning (Bergh et al. 2014). Despite that thinning reduces tree biomass, and presumably also $\mathrm{C}$ input into the soil, thinning effects on soil $\mathrm{C}$ stocks have appeared to be minor (Mayer et al. 2020). However, when evaluating over-all effects of thinning on long-term $\mathrm{C}$ accumulation, both standing biomass and soil, as well as $\mathrm{C}$ potentially stored in removed timber have to be included.

Although not as common as thinning, nitrogen (N) fertilization is a management alternative that can promote net $\mathrm{C}$ uptake in trees due to strong $\mathrm{N}$ limitation in most forests (Högberg et al. 2017; Hyvönen et al. 2008; Tamm 1991; Vitousek and Howarth 1991). Increased $\mathrm{N}$ input, through atmospheric deposition or fertilization, can also promote $\mathrm{C}$ sequestration in the organic horizon (Magnani et al. 2007; Hyvönen et al. 2008; de Vries et al. 2009; Maaroufi et al. 2015; Tipping et al. 2017). Fertilization can promote belowground $\mathrm{C}$ sequestration by stimulating inputs, but also by reducing decomposition (Janssens et al. 2010). This can be achieved either via changes in composition and activity of decomposer communities (Entwistle et al. 2017), or by interference with mycorrhizal symbiosis (Baskaran et al. 2017). However, as extensive thinning may decrease photosynthesis and $\mathrm{C}$ fluxes to biomass and soils, and thereby reduce the potential of fertilization to stimulate $C$ sequestration, interactive effects between thinning practices and fertilization are likely and potentially important when guiding management towards increased $\mathrm{C}$ sequestration.

Increased $\mathrm{N}$ input can shift nutrient stoichiometry towards higher N:P ratios, which may lead to phosphorus (P) limitation and impaired growth, at least in more nutrient rich, temperate systems (Braun et al. 2010). Twenty years of $\mathrm{N}$ additions increased the N:P ratio in Picea abies needles, but not to such extent that growth was reduced, with no indication of P limitation (Palmqvist et al. 2020). On the other hand, Hyvönen et al. (2008) observed lower N use efficiency on tree growth in forests fertilized with $\mathrm{N}$ only compared to combined $\mathrm{N}, \mathrm{P}$ and potassium (K) fertilization. 
Although there is a prospect to manage boreal forests towards improved $\mathrm{CO}_{2}$ withdrawal through thinning and fertilization, $\mathrm{C}$ sequestration is not the only ecosystem service that boreal forests provide. For example, production of high quality saw-timber may not always go hand in hand with maximized biomass production and $\mathrm{C}$ sequestration, and forest management often interacts and/or interferes with a number of other ecosystem properties with potentially conflicting goals (Strengbom et al. 2018). Leaching of nutrients, both during and after the forest rotation period, is of particular concern. Although boreal forests are strongly $\mathrm{N}$ limited (Högberg et al. 2017), additions of $\mathrm{N}$ may render them $\mathrm{N}$ saturated and cause leaching and eutrophication of water (Aber et al. 1989). There is also a major risk that forest thinning and fertilization operations lead to losses of biodiversity (Strengbom and Nordin 2008).

Here, we used a 40-year field trial that studied interactive effects of fertilization $(\mathrm{N}$ and $\mathrm{P})$ and thinning across a boreal latitudinal gradient in Sweden to estimate the potential of managing boreal Scots pine (Pinus sylvestris) dominated forests towards increased $\mathrm{C}$ sequestration. We aimed to assess effects on $\mathrm{C}$ accumulation in standing tree biomass and the organic horizon, as well as in timber removed during thinning operations. To explore the mechanisms behind changes in belowground $\mathrm{C}$ stocks, we investigated the balance between $\mathrm{C}$ losses in the form of soil respiration and $\mathrm{C}$ inputs based on tree productivity. We also measured levels of inorganic $\mathrm{N}$ (nitrate and ammonium) in the soil.

\section{Material and methods}

\section{Experimental design and tree monitoring}

We used 29 Scots pine (Pinus sylvestris L.) dominated forest stands (percent pine of total stem volume: $\mathrm{min}$ $84 \%$, median $100 \%$ ) from a long-term thinning and fertilization experiment established along a $1300 \mathrm{~km}$ latitudinal gradient $\left(56-67^{\circ} \mathrm{N}\right)$ in Sweden. The experiment was initiated between 1969 and 1982, when the sites were at canopy closure, i.e. at the time when operational thinning would be performed according to standard silvicultural practice. Depending on latitude, this occurred when the stands were between 32 and 54 years old. At the time of our field campaign in 2016, the stands were between 65-99 years old. The experimental plot net size was typically $25 \times 40 \mathrm{~m}(0.1 \mathrm{ha})$ with a surrounding buffer zone of $10 \mathrm{~m}$, and we sampled four treatments at each of the 29 sites: "no thinning", "thinning", "thinning $+\mathrm{N}$ " and "thinning $+\mathrm{N}+\mathrm{P}$ ". At nine sites distributed along the gradient, an additional treatment of "no thinning $+\mathrm{N}$ " was also sampled, making the total number of plots 125 . Thinning operations occurred one to four times during the experimental period (Supplementary table 1), with the first thinning conducted when the trees were between 12 and $16 \mathrm{~m}$ high. Due to variation in initial basal area, the intensity of the initial thinning varied among sites, but corresponded on average to a $20-25 \%$ reduction in basal area. Subsequent thinning aimed to keep the basal area constant over time at around $18 \mathrm{~m}^{2} \mathrm{ha}^{-1}$ (Nilsson et al. 2010). Since the aim of the thinning was to achieve an even spatial distribution of healthy residual stems, trees with low vitality and severe damage were removed at the time of thinning as well as other species than pine. Only stems were removed, and tops and branches (including needles) were left in the plots. Nitrogen was added as ammonium nitrate $\left(\mathrm{NH}_{4} \mathrm{NO}_{3}\right)$ at a rate of $100-150 \mathrm{~kg} \mathrm{~N} \mathrm{ha}^{-1}$ every $5^{\text {th }}$ year for the first 25 years, and thereafter every $7^{\text {th }}$ year. Phosphorus was added as superphosphate $\left(\mathrm{CaSO} 4+\mathrm{Ca}\left(\mathrm{H}_{2} \mathrm{PO}_{4}\right)_{3}\right)$ corresponding to $100 \mathrm{~kg} \mathrm{P} \mathrm{ha}^{-1}$ at the initiation of the experiment, and thereafter the same dose every 20-21 years. The experimental set-up is described in more detail in Nilsson et al. (2010) and Bergh et al. (2014), as well as in Supplementary table 1 .

All trees within the plots were individually marked, and measured (height and diameter at breast height) at the initiation of the experiment as well as at the end of the study period. The diameter of trees removed during thinning, or by accidental windfalls, were measured at five or six occasions over the experimental period.

Sampling and chemical analyses of the organic horizon

All stands in the study had podzol soils with an organic horizon thickness ranging 2.5 to $11.7 \mathrm{~cm}$ (average: $5.9 \mathrm{~cm}$ ), which had a $\mathrm{C}: \mathrm{N}$ ratio of $25.2-62.8$ (average: 40.6), and a pH of 3.3-4.6 (average: 3.7). In July 2016, we sampled the organic horizon (O-horizon) at 26 of the sites by pooling 25 soil cores $(3 \mathrm{~cm}$ 
in diameter) collected in a grid pattern across each 0.1 ha plot. Due to logistic problems, 3 sites were sampled during the same period the following year. Living plants and litter (equivalent to the Oi horizon, commonly accounting for less than $5 \%$ of the $\mathrm{C}$ in the organic horizon (Sterkenburg et al. 2018)) were removed from the soil surface before sampling. The underlying mineral soil layer was removed together with larger roots $(>2 \mathrm{~mm})$, and the organic horizon (Oe and $\mathrm{Oa}$ ) of the 25 cores was pooled into a single composite sample per plot. The transition from organic horizon to mineral soil was generally sharp, but in cases where the transition was more gradual we chose to include the uppermost part of the mineral soil together with the organic horizon rather than discarding parts of the organic horizon. The soil samples were put in a cooler and frozen $\left(-20^{\circ} \mathrm{C}\right)$ within $48 \mathrm{~h}$.

Organic matter concentration $(\mathrm{OM})$, mineral $\mathrm{N}$ availability, and $\mathrm{C}$ and $\mathrm{N}$ concentration in the organic horizon were determined from subsamples after homogenization of the frozen composite sample. OM content was determined by accounting for water content (drying at $105^{\circ}$ for $24 \mathrm{~h}$ ). A subsample was freeze-dried and finely ground in a ball mill before determination of $\mathrm{C}$ and $\mathrm{N}$ concentration in $0.4 \mathrm{~g}$ of soil in a combustion elemental analyzer (TruMac CN, LECO, Saint Joseph, MI, USA). Ammonium $\left(\mathrm{NH}_{4}{ }^{+} \mathrm{N}\right)$ and nitrate $\left(\mathrm{NO}_{3}{ }^{-} \mathrm{N}\right)$ concentrations were analyzed from extracts with a 1:2.5 mass ratio of freshly frozen soil and $2 \mathrm{M} \mathrm{KCl}$ in an Autoanalyzer (BRAN-LUEBBE XY-2 Sampler, SEAL Analytical Inc., Australia) and scaled to $\mathrm{mg} \mathrm{N} \mathrm{m}^{-2}$ (sampled soil dry weight $\times$ inorganic- $\mathrm{N}$ concentration, divided by the area of the 25 sampling cores).

\section{Carbon stocks}

The organic $\mathrm{C}$ stock of the organic horizon was calculated as soil dry weight $(\mathrm{DW}) \times \mathrm{C}$ concentration, and scaled up to tonnes ( $\mathrm{t}$ ) $\mathrm{ha}^{-1}$ based on the added area of the 25 sampling cores. Biomass of trees was estimated using allometric functions based on plot average tree stem diameter and height (Marklund 1988) (Supplementary Material and Method) for Scots pine, Norway spruce and birch (as a proxy for all deciduous trees) multiplied by the number of trees. For biomass of trees removed during thinning, the height of the trees was estimated
(Laasasenaho 1982) before using the allometric functions. For belowground biomass of the trees, we used the allometric functions developed by Petersson and Ståhl (2006). Our allometric functions provided biomass estimates of wood, branches and needles, stump and coarse roots $(>2 \mathrm{~mm})$. The fine root biomass $(<2 \mathrm{~mm})$ was included as part of the organic horizon pool. The above allometric functions have been shown to be very robust along latitudinal and fertility (i.e., stand index) gradients in Sweden. Marklund (1988) reported only marginally improved predictability when adding one of these predictors. For example, the $\mathrm{R}^{2}$ value of the pine stump model increased from 0.972 to 0.978 when including latitude as a predictor. Hence, our biomass estimates should not be biased across the latitudinal gradient or treatments, with the cautionary note that the allometric functions have not been tested for highly fertilized trees.

We estimated $\mathrm{C}$ stocks in standing and removed biomass by assuming a 50\% C-content (Neumann et al. 2016). In the ecosystem calculations, we included $\mathrm{C}$ stock in trees (including coarse roots) and in the organic horizon but assumed no changes in $\mathrm{C}$ stocks in the mineral soil and shrub layer. Changes in $\mathrm{C}$ stocks in response to management were calculated in two different ways. In the first approach, we only considered $\mathrm{C}$ that was stored at site, i.e. in standing biomass, roots and organic horizon. In an alternative approach, we also included $\mathrm{C}$ in wood removed during thinnings, which potentially may be stored outside the forest, in timber or forestry products. In reality, the degree and durability of $\mathrm{C}$ storage in removed wood depend on its subsequent fate. A proper life cycle analysis (LCA) was outside the scope of this study, and our two approaches can be interpreted as boundary estimates. However, assuming a 30-46-24\% distribution of harvested biomass between wood products, paper/pulp and fuel for energy production, respectively (Lundmark et al. 2014), and an average half time of 30 years for $\mathrm{C}$ in wood products and 2 years for C in paper/pulp or fuelwood (IPCC 2006), the expected half-time of $\mathrm{C}$ stored in forest products can be estimated to around 10 years. 
Soil respiration

Soil $\mathrm{CO}_{2}$ flux $\left(\mathrm{R}_{\mathrm{s}}\right)$ measurements were recorded in 2017 on rain-free days between June $29^{\text {th }}$ and July $29^{\text {th }}$ in all treatments except "thinning $+\mathrm{NP}$ ", summing up to 96 measured plots. We measured soil $R_{s}$ from south to north to track phenological advancement of the vegetation, so that all sites were measured at a similar phenological stage. In each plot, we measured $\mathrm{R}_{\mathrm{s}}$ at ten evenly distributed positions, distanced at least $0.5 \mathrm{~m}$ from the plot edge and from the nearest tree. Based on a pilot power analysis on $\mathrm{R}_{\mathrm{s}}$ measurements from 20 locations within a 0.1 ha plot, similar to the experimental sites, we concluded that ten samples would be sufficient to detect a $15 \%$ change in $\mathrm{R}_{\mathrm{s}}$ from $100 \mathrm{mg} \mathrm{C} \mathrm{m}^{-2} \mathrm{~h}^{-1}$.

$\mathrm{R}_{\mathrm{S}}$ was measured in a closed chamber constructed by a PVC collar (diameter $=30 \mathrm{~cm}$, height $=14.5 \mathrm{~cm}$, internal volume $=10.2 \mathrm{dm}^{3}$ ). To minimize the influence of aboveground plant respiration, we removed all living ground vegetation before gently pushing the chamber $0-1 \mathrm{~cm}$ into the soil. $\mathrm{R}_{\mathrm{s}}$ was estimated by use of a portable soil respiration chamber and a portable infrared $\mathrm{CO}_{2}$ gas analyzer (Vaisala GMP343). $\mathrm{CO}_{2}$ concentration was recorded at 15-s intervals during $3 \mathrm{~min}$. To calculate $\mathrm{CO}_{2}$ exchange rate, we fitted a quadratic relationship between $\mathrm{CO}_{2}$ and time, where the linear term is the estimated exchange rate. A quadratic model gives a more accurate exchange rate (Kutzbach et al. 2007), and during field measurements, we noticed that the increase in $\mathrm{CO}_{2}$ concentration levelled off with time. $\mathrm{R}_{\mathrm{s}}$ was calculated on an area basis (mg C m${ }^{-2} \mathrm{~h}^{-1}$ ) accounting for chamber temperature and volume according to standard equations (Kutzbach et al. 2007).

After each $\mathrm{R}_{\mathrm{s}}$ measurement, we recorded soil water content (WC) and soil temperature within the collar. We measured WC with a soil moisture sensor (Meter GS3 probe with a Pro-check reader) and used the mean value of four recordings. To measure soil temperature, a digital lab thermometer (TFA LT-101) was inserted into the organic soil layer and left for one minute before recording the temperature.

\section{Statistical analysis}

To test the effect of treatments and environmental variables on response variables, we used linear mixed models (LMM) in the lme4 package (Bates et al. 2015) of R 3.5 ( $\mathrm{R}$ Core Team 2018). Thinning was included as a fixed factor, while $\mathrm{N}$ application was included as a continuous variable corresponding to the accumulated $\mathrm{N}$ load at the time of the field sampling, to account for variation in $\mathrm{N}$ load between sites. To make interpretation easier, $\mathrm{N}$ application was standardized by the mean $\mathrm{N}$ application. Thus, one unit change in $\mathrm{N}$ application (i.e. the effect size in our models) corresponded to the mean $\mathrm{N}$ application (881 $\mathrm{kg} \mathrm{ha}^{-1}$ ) and the standardized range $(0.6-1.7)$ corresponded to an actual range of $\left(500-1200 \mathrm{~kg} \mathrm{ha}^{-1}\right)$. We included $\mathrm{P}$ addition as a factor (not for the $\mathrm{R}_{\mathrm{s}}$ model), but as this treatment always was applied in combination with the $\mathrm{N}$ and thinning treatments, its additive effect was modelled in combination with these treatments. To assess if the effect of the management regimes changed across the latitudinal gradient, we ran models where we included the interactive effect of treatment and latitude. Site was included as a random factor, and for the $R_{s}$ model, treatment plot was added as an additional random factor nested under site to account for multiple samples within a plot. $\mathrm{R}_{\mathrm{s}}$ is modified by soil temperature and moisture (Davidson et al. 1998), and we therefore included these variables as covariates to control for local effects. As expected, these variables had an influence on $\mathrm{R}_{\mathrm{s}}$, but due to a technical failure, soil water content was not recorded at two sites. To be able to include these sites in the full model, we employed an imputation method implemented in the R package amelia (Honaker et al. 2011), which creates many data sets with imputations, run individual models, and finally average these models to account for extra variation due to imputation. Given the high replication, we calculated effect-size uncertainties (95\% confidence interval) and P-values based on Wald statistic. Residuals were visually checked for homogeneity and normality. The residual variance of the $R_{s}$ model increased with $R_{s}$, wherefore $\mathrm{R}_{\mathrm{s}}$ was $\log$-transformed. We also plotted the soil temperature at the time of $\mathrm{R}_{\mathrm{s}}$ measurement against latitude to evaluate if there were any systematic differences in temperature across the latitudinal transect (Supplementary Fig. 1). Tables were produced using the sjPlot package (ver 2.6.2) (Lüdecke 2018). Treatment effects are evaluated relative to thinning without fertilization, which is the standard silvicultural practice in Swedish forestry. 


\section{Results}

First we only considered $\mathrm{C}$ stored at the site, as a boundary estimate that assumes that all $\mathrm{C}$ in removed biomass is rapidly returned to the atmosphere. Fertilization combined with abstention from thinning increased the $\mathrm{C}$ stock by $90 \mathrm{t} \mathrm{C}^{-1}$ (CI: 80-100) $(+79 \%)$ over a 40 -year period, compared to the standard practice of thinning without fertilization (Fig. 1a, Supplementary table 2). A major fraction of the increased sequestration (84 t C ha ${ }^{-1}$, CI: 74-93) occurred through increased production and retention of standing biomass, while increased $\mathrm{C}$ storage in the organic horizon accounted for a smaller proportion (6 $\mathrm{t} \mathrm{C} \mathrm{ha}^{-1}$, CI: 3-9). Abstaining from thinning alone increased the total $\mathrm{C}$ stock by $57 \mathrm{t} \mathrm{C} \mathrm{ha}^{-1}$ (CI: $50-64)(+50 \%)$ but had no significant effect on soil C. Both biomass production and organic horizon $\mathrm{C}$ storage were stimulated by $\mathrm{N}$ additions. The increase was most pronounced when fertilization and abstention from thinning were combined, as indicated by a significant interaction effect. Repeated $\mathrm{N}$ fertilization, on average $881(500-1200) \mathrm{kg} \mathrm{N} \mathrm{ha}^{-1}$ over the 40 year period, increased the ecosystem $\mathrm{C}$ stock by $12 \mathrm{t} \mathrm{C} \mathrm{ha}^{-1}$ (CI: 5-19) (+11\%) in thinned stands, and by $33 \mathrm{t} \mathrm{C} \mathrm{ha}^{-1}$ (CI: 23-42) (+19\%) without thinning (Fig. 1c). Complementation of the $\mathrm{N}$ fertilization with $\mathrm{P}$ had no effect on tree growth, but increased the organic horizon $\mathrm{C}$ stock in thinned stands by $3 \mathrm{t} \mathrm{C}$ $\mathrm{ha}^{-1}$ (CI: $1-5$ ) relative to $\mathrm{N}$ fertilization only (Fig. 1a, Supplementary table 2).

In a second scenario, we included the $\mathrm{C}$ that had been removed from the stands during thinning in the total $\mathrm{C}$ stocks, as a boundary case where all removed $\mathrm{C}$ was assumed to remain sequestered in stored wood and forest products (Fig. 1c, Supplementary table 2). Fertilization combined with abstention from thinning then increased the $\mathrm{C}$ stock by $53 \mathrm{t} \mathrm{ha}^{-1}$ (CI: 45-61) $(+35 \%)$ compared to the standard practice of thinning without fertilization. Inclusion of the $\mathrm{C}$ storage in thinned timber did not eliminate the positive effect of abstention from thinning, indicating that total production was higher in stands left without thinning. Furthermore, the positive effect of fertilization on $\mathrm{C}$ sequestration was again higher without thinning compared to thinned stands.

When we modelled the potential of changed management regimes across latitudes, we found that the positive effect of $\mathrm{N}$ addition on above- and below-ground $\mathrm{C}$ sequestration was highest in the low-productive ecosystems in the northern parts of the boreal zone (Fig. 2, Supplementary table 3). The interaction between latitude and thinning was associated with a large uncertainty (Organic horizon: $\mathrm{P}=0.69$, Net tree production: $\mathrm{P}=0.13$ ). For simplicity and robustness of the model, we therefore removed this interaction term from the model.

The combination of fertilization and abstention from thinning decreased soil respiration by $19 \%$ (CI: 5-31) compared to the unfertilized, thinned stands (Fig. 3, Supplementary table 4). The other treatments had no significant effect. Within treatments, soil C stocks were not positively linked to tree growth; in fact, there was a marginally significant negative correlation (Fig. 4, Supplementary table 5). Latitude had no influence on soil respiration $(\mathrm{P}=0.85)$ and was excluded from the model.

Mineral N levels were slightly elevated, although not statistically significant, after $\mathrm{N}$ fertilization. This increase was entirely ascribed to ammonium, whereas the contribution of nitrate was low and generally close to the detection limit (Fig. 5, Supplementary table 6).

\section{Discussion}

Compared to the standard silvicultural practice of thinning, both abstention from thinning and fertilization had a major influence on $\mathrm{C}$ accumulation in Scots pine forests. While the main purpose of thinning in forestry is to increase timber quality and provide early economic revenue during a forest rotation cycle, thinning may also reduce competition for nutrients and light, which in turn is expected to increase growth of the remaining trees (Royal Swedish Academy of Agriculture and Forestry 2015). Here, thinning reduced over-all $\mathrm{C}$ accumulation in stands irrespective of whether $\mathrm{C}$ in harvested timber was included or not. This result is in accordance with other thinning trials in boreal Fennoscandian (Mäkinen and Isomäki 2004), Mediterranean (Bravo-Oviedo et al. 2015), Central European (Seidl et al. 2007), and temperate regions of central North America (Powers et al. 2011). Without fertilization, we found no effect of thinning on the $\mathrm{C}$ stock in the organic horizon. Similarly, a meta-analysis concluded that, although thinning commonly reduces litter input in coniferous 
(a)

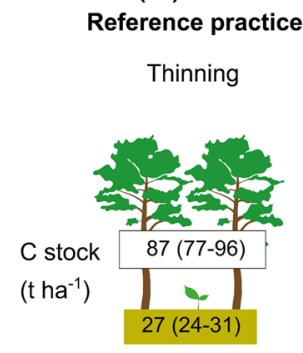

(b)

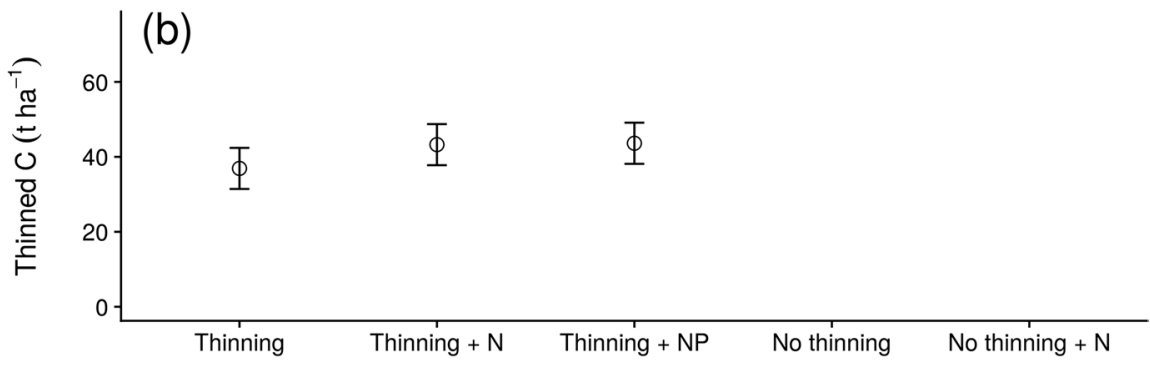

Effect of management scenarios

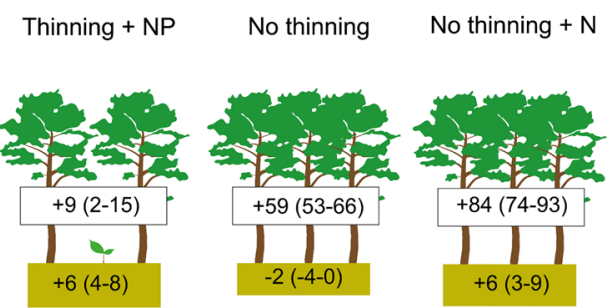

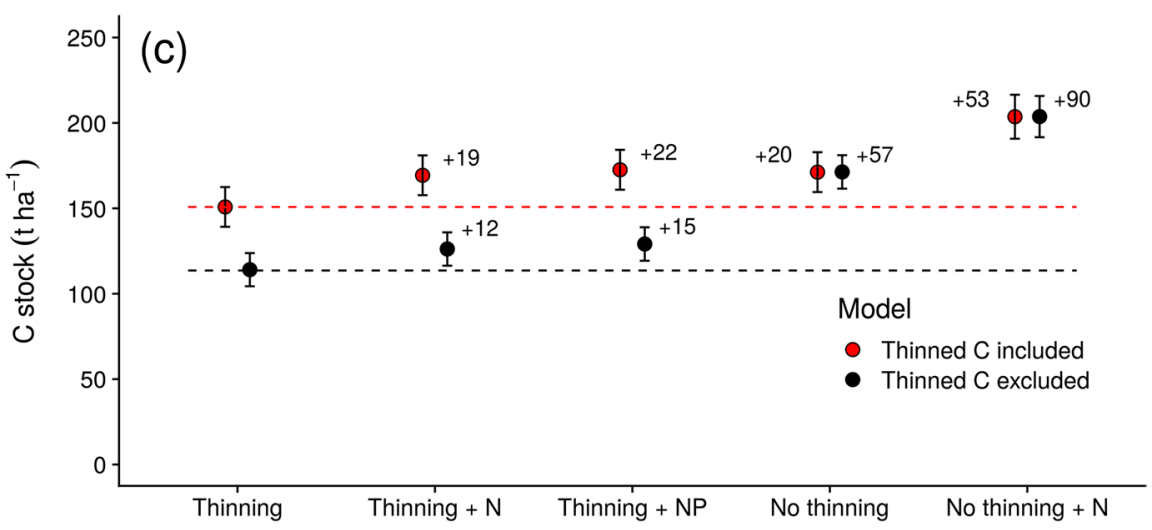

Fig. 1 Effects of different management scenarios on $\mathrm{C}$ stocks (trees, organic horizon), $\mathrm{C}$ removed by thinning, and total ecosystem C gain. (a) Tree and organic horizon C stocks in stands subjected to the standard silvicultural practice of thinning and the effect of different alternative management scenarios, applied over a period of 40 years. (b) $\mathrm{C}$ removed during thinning operations. (c) Ecosystem $\mathrm{C}$ stocks under different management scenarios and associated effects on net $\mathrm{C}$ sequestration (numbers beside the points). Red symbols represent

forests, the effects on the soil C stock are often small (Zhang et al. 2018).

The strong positive effect of fertilization on tree growth confirms earlier findings from boreal forests (Bergh et al. 2014; Högberg et al. 2017; Hyvönen et al. 2008; Tamm 1991; Valinger et al. 2000). The stimulation of $\mathrm{C}$ sequestration in trees was, however, not large enough to compensate for $\mathrm{C}$ losses during

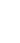



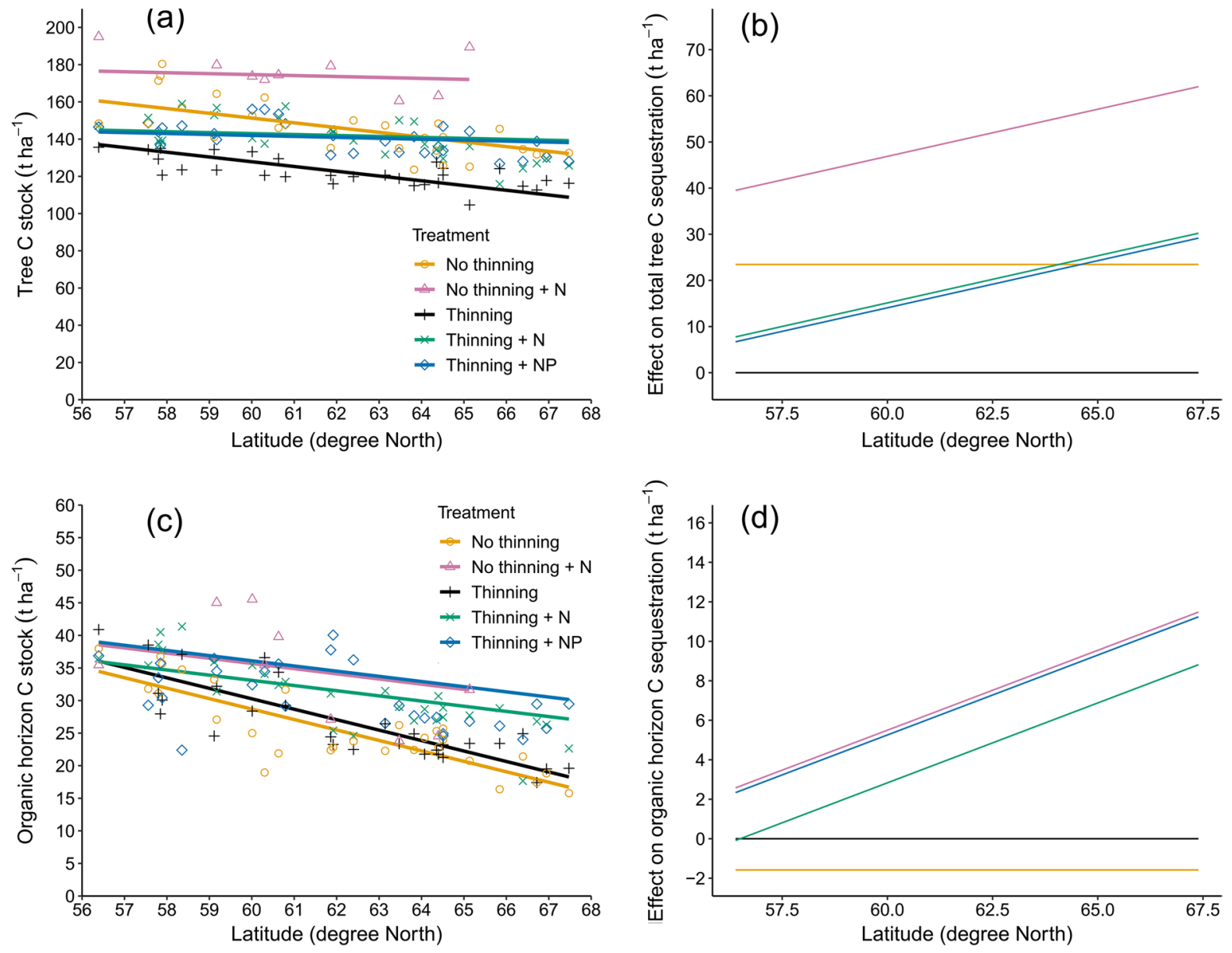

Fig. $2 \mathrm{C}$ stocks in (a) trees (including $\mathrm{C}$ removed by thinning) and (c) organic horizon, and model estimates of treatment effects on (b) tree net $\mathrm{C}$ uptake, and (d) organic horizon $\mathrm{C}$ accumulation. Colors represent different management sce-

narios and their effects compared to the standard silvicultural practice of commercial thinning without fertilization, indicated in black. See Supplementary table S3 for statistics

The observed increases in organic horizon $\mathrm{C}$ stocks after nutrient addition are in line with previous studies (Hyvönen et al. 2008; Janssens et al. 2010; Maaroufi et al. 2015). Although the belowground C sink was much smaller than sequestration in tree biomass, changes may still be more important from a climate mitigation perspective, as they can be assumed to represent a more stable and long-lasting form of $\mathrm{C}$ sequestration (Kyaschenko et al. 2019; Rumpel et al. 2002; Schulze et al. 2009). Nevertheless, the longterm stability of the soil $\mathrm{C}$ sink induced by fertilization remains an open question.

The observed decrease in respiration following fertilization (Fig. 3) and the increase in the organic horizon $\mathrm{C}$ stock (Fig. 1a) indicate decreased rates

of decomposition, corroborating previous studies (Janssens et al. 2010; Maaroufi et al. 2015; Zak et al. 2008). If anything, soil C stocks correlated negatively with tree productivity within treatments (Fig. 4), supporting the idea that variation in $\mathrm{C}$ input has marginal influence on belowground $\mathrm{C}$ accumulation (Lajtha et al. 2018; Terrer et al. 2021). Rather, variation in decomposition rates (Janssens et al. 2010; Kyaschenko et al. 2017b; Stendahl et al. 2017), in particular of root derived C (Clemmensen et al. 2013; Kyaschenko et al. 2019) seems to play a dominant role in regulating the below-ground $\mathrm{C}$ pool. Increased $\mathrm{N}$ availability after fertilization may decrease the need for microbial exploitation of organic stocks for nutrients, leading to decreased 


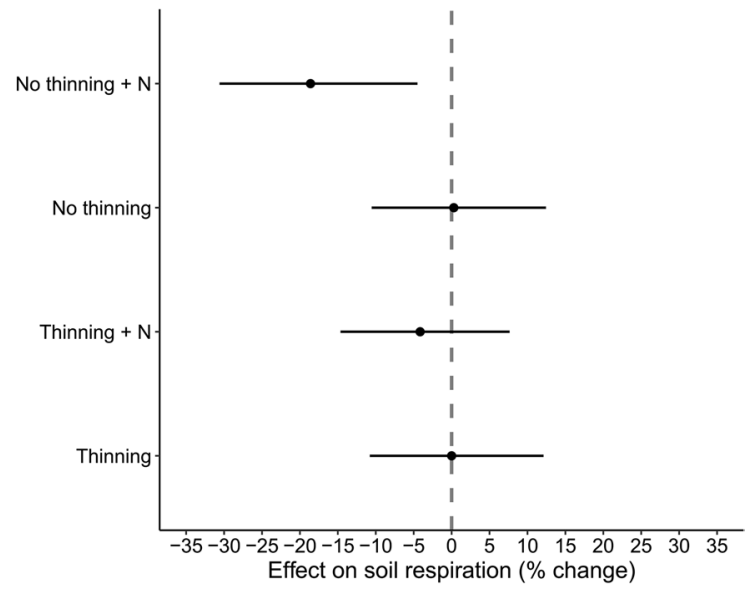

Fig. 3 Model estimates of treatment effects on soil respiration, calculated on a per area $\left(\mathrm{R}_{\mathrm{s}}\right)$ basis, are adjusted for variation in soil temperature and water content. Effects are related to the standard silvicultural practice of thinning without fertilization. Bars indicate $95 \%$ confidence intervals. See Supplementary table S4 for statistics and Supplementary file 3 for estimates

decomposition (Entwistle et al. 2018; Terrer et al. 2021). In boreal forests, ectomycorrhizal fungi have been proposed to regulate belowground $\mathrm{C}$ accumulation through their mining (i.e. decomposition) of organic matter for $\mathrm{N}$ (Clemmensen et al.
2013; Lindahl and Tunlid 2015; Sterkenburg et al. 2018). Negative effects of fertilization on mycorrhizal fungi specialized in exploitation of organic nutrients (Baskaran et al. 2017) may shift both functioning and composition of fungal communities (Högberg et al. 2010; Lilleskov et al. 2002; Maaroufi et al. 2019). However, we observed no decrease in respiration after fertilization of thinned stands, which is in agreement with the lower $\mathrm{C}$ accumulation observed in these stands. Potentially, thinning increases availability of high $\mathrm{C}: \mathrm{N}$ substrates in the form of dead roots as well as branches and needles left in the plot, which may maintain $\mathrm{C}$ supply and $\mathrm{N}$ limitation of the decomposer community. Thus, similarly to aboveground responses, the positive effect of fertilization on below-ground $\mathrm{C}$ sequestration was highest in the absence of thinning.

Surprisingly, supplementation of $\mathrm{N}$ fertilization with additional $\mathrm{P}$ increased organic horizon $\mathrm{C}$ sequestration even further (Fig. 1a). We do not have respiration data for the plots supplemented with $\mathrm{P}$, but we speculate that the higher $\mathrm{C}$ stock is a result of further reduced decomposition. When $\mathrm{N}$ limitation is alleviated by fertilization, $\mathrm{P}$ may become a limiting factor (Aber et al. 1989; Braun et al. 2010) that could stimulate microbial decomposers to mine P from organic matter (Forstner et al. 2019; Widdig
Fig. 4 Relationship between soil C stocks and tree productivity $(\mathrm{t}$ $\mathrm{yr}^{-1} \mathrm{ha}^{-1}$ ) within different treatments. See Supplementary table S5 for statistics

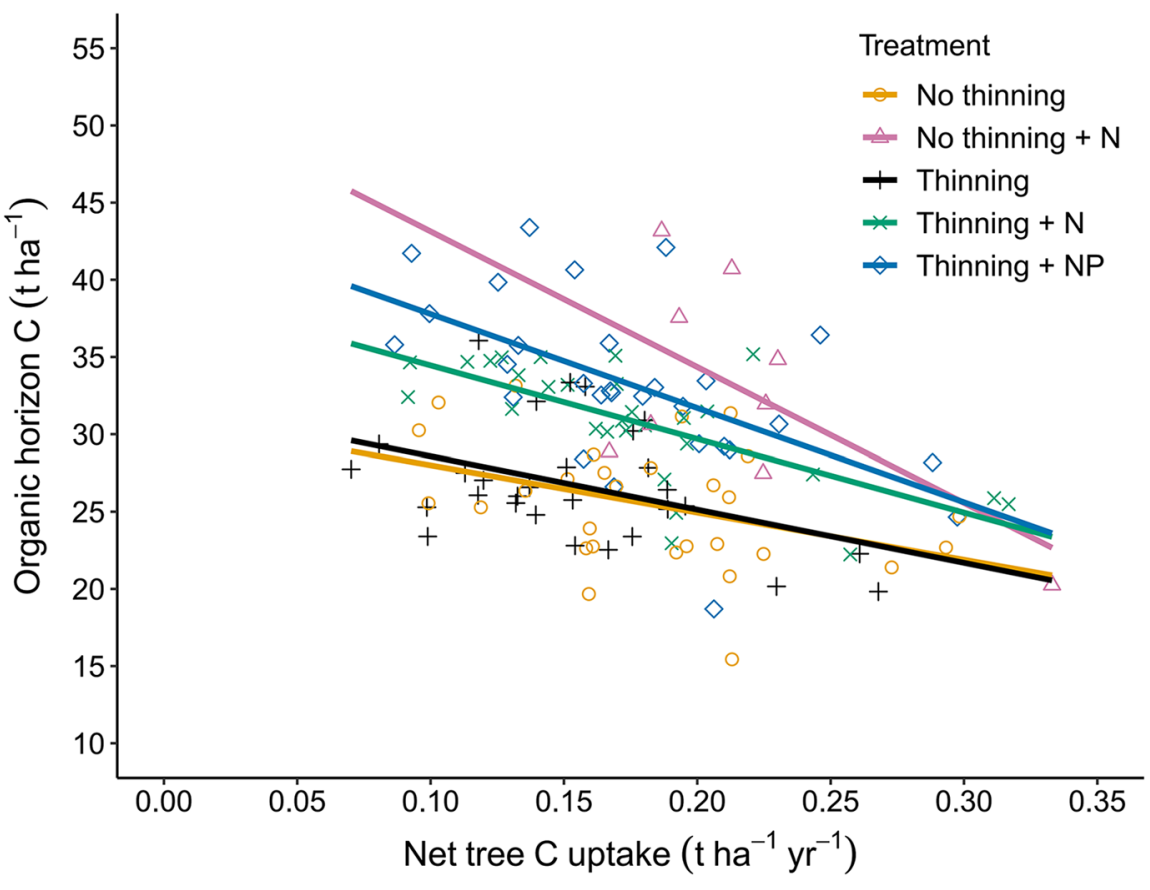



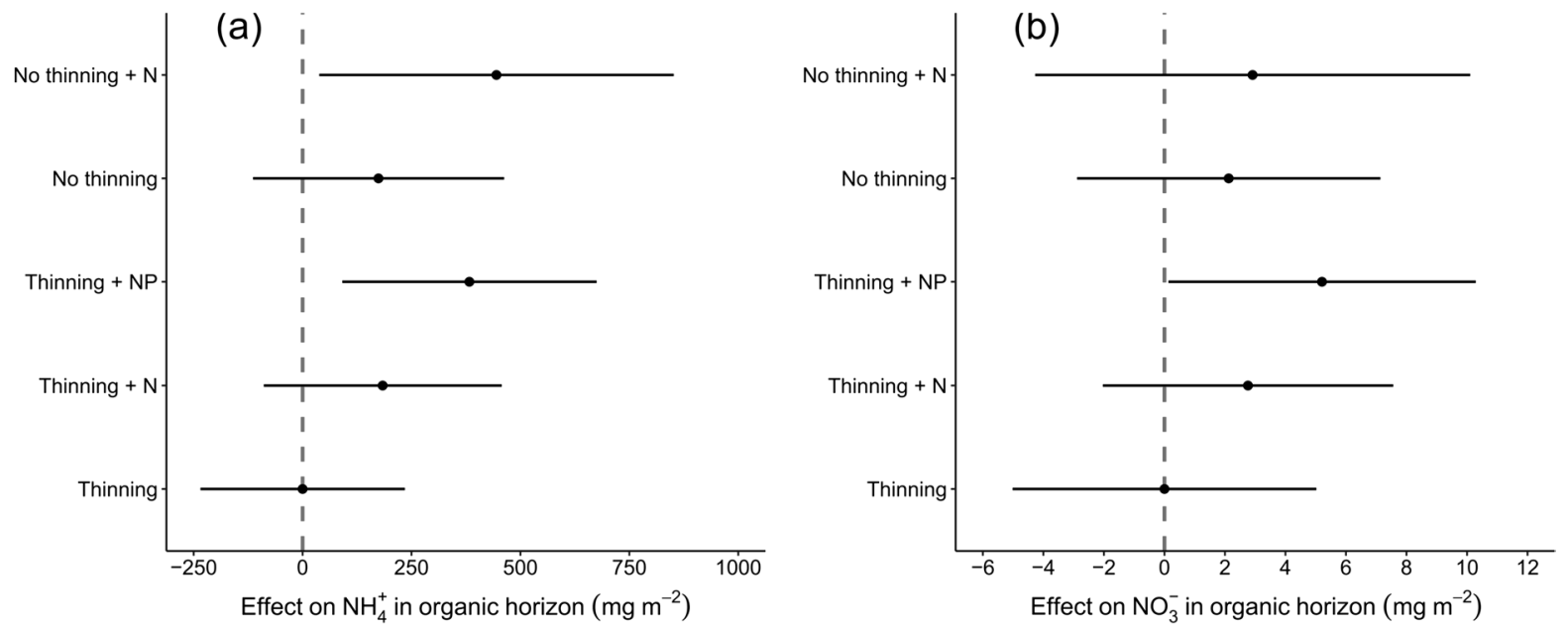

Fig. 5 Treatment effects on extractable a) ammonium and b) nitrate in the organic horizon. Bars indicate $95 \%$ confidence intervals. See Supplementary table S6 for statistics

et al. 2019). However, (Forsmark et al. 2020) did not find any evidence for that higher microbial $\mathrm{P}$ mobilization in response to $\mathrm{N}$ enrichment would affect soil C storage.

A potential problem with adaptation of forest management to increase soil $\mathrm{C}$ stocks is the possibility that a substantial part of the accumulated soil $\mathrm{C}$ stock may be lost after clear-felling (James and Harrison 2016; Nave et al. 2010). Soil temperature and moisture are key factors controlling decomposition rates (Swift et al. 1979), and clear-felling influence both (Jansson 1987), with a risk of destabilization of soil C. Below-ground C stocks also depend on plantsoil feedbacks and are expected to be sensitive to the removal of mycorrhizal trees at harvest (Kyaschenko et al. 2017a). However, whether loss of mycorrhizal activity stabilize or destabilize the organic matter, remains unresolved (Frey 2019; Sterkenburg et al. 2018).

$\mathrm{N}$ fertilization affected $\mathrm{C}$ sequestration at all latitudes, but the marginal effect of additional $\mathrm{N}$ supply was larger at higher latitudes (Fig. 2). Nutritional constraints on $\mathrm{C}$ cycling may be stronger at higher latitudes, with nutrients locked up in recalcitrant organic pools and mycorrhizal interactions playing a central role in organic matter dynamics (Clemmensen et al. 2013; Lindahl and Tunlid 2015). Fertilization may reduce the impetus for mycorrhiza-driven exploitation of organic nitrogen and associated organic matter oxidation (Bödeker et al. 2014). In addition, anthropogenic $\mathrm{N}$-deposition at the southern sites has altered soil $\mathrm{C}: \mathrm{N}$ ratios, which may lower effects of additional nutrient enrichment at the southern sites in our experiment (Van Sundert et al. 2018).

Taken together, our results support previous findings and demonstrate that changed management can promote $\mathrm{C}$ sequestration, achieving significant gains within decades and, potentially, contribute towards the zero net-emission goal. We identified abstention from commercial thinning combined with fertilization as a particularly efficient way to increase $\mathrm{C}$ sequestration. Such management seems to have great potential as a "natural solution" to counter climate change. The effect of management on $\mathrm{C}$ stocks differed substantially depending on whether the $\mathrm{C}$ in harvested timber was included or not (Fig. 1). This highlights the importance of the downstream use of extracted biomass (Baul et al. 2017), i.e. if the removed wood is used primarily in products with a long residence time, or to produce short-lived products, such as paper. A rough calculation estimates that $\mathrm{C}$ in harvested biomass returns to the atmosphere after, on average, 10 years, but substitution of fossil fuels may add further to climate change mitigation. A proper LCA is needed to fully assess the climate change mitigation potential of forestry, a task that, however, goes beyond the scope of this paper. In this study, we have only examined the effects on $\mathrm{C}$ stocks in the system, without considering the $\mathrm{C}$-cost of implementing 
the different management options. However, LCAs on the production of $\mathrm{NH}_{4} \mathrm{NO}_{3}$ as a fertilizer in agriculture estimated the $\mathrm{C}$ footprint to circa $1.7 \mathrm{~kg} \mathrm{C}$ $\mathrm{kg} \mathrm{N}^{-1}$ (6.2 $\mathrm{CO}_{2}$ eq.), which would amount to circa $1.5 \mathrm{t} \mathrm{C} \mathrm{ha}^{-1}$ in our study (Skowrońska and Filipek 2014), thus having a rather small impact on the net $\mathrm{C}$ accumulation.

Due to their strong $\mathrm{N}$ limitation, boreal forests have high capacity to retain external $\mathrm{N}$ input (Binkley and Högberg 2016; Kjønaas and Wright 2007; Näsholm et al. 2013). However, at some point of $\mathrm{N}$ input the $\mathrm{N}$ retention capacity will be saturated, resulting in increased nitrification and the risks of gaseous or leaching losses of $\mathrm{N}$, with subsequent increased risk of eutrophication of neighboring ecosystems (Aber et al. 1989). The high mobility of nitrate in soils makes nitrification especially problematic, but the high $\mathrm{N}$ retention of boreal forests likely makes them resistant to high rates of $\mathrm{N}$ input (Ring et al. 2011). Although we observed somewhat elevated ammonium concentrations in the fertilized plots, nitrate levels were generally below the detection limit (Fig. 5). Thus, we suspect that most of the fertilizer applied during the 40-year experimental period $\left(500-1200 \mathrm{~kg} \mathrm{~N} \mathrm{ha}^{-1}\right)$ was retained in soil and biomass, and that the experimental sites remain below $\mathrm{N}$ saturation.

Although promising, management alterations to increase $\mathrm{C}$ sequestration should be evaluated against trade-offs in the delivery of other ecosystem services provided by boreal forest. For example, there is a risk that forestry directed towards increased $\mathrm{C}$ sequestration, via fertilization and abstention from commercial thinning, leads to biodiversity loss (Allison et al. 2007; Strengbom et al. 2011), as well as reduced delivery of other ecosystem services, such as production of wild berries and reindeer fodder (Strengbom et al. 2018). However, the net loss of such services can probably be reduced if C-oriented management is constrained to secondary forests, exposed to clearcut forestry, which presumably have already lost large parts of their original values.

Supplementary Information The online version contains supplementary material available at https://doi.org/10.1007/s11104021-05038-0.

Acknowledgements We thank Kateřina Beňová, Sandra Walther and Leo Ruth for help collecting soil samples and conducting the soil respiration measurements, and $\mathrm{K}$
Clemmensen and C Evans for comments on previous drafts of the manuscript.

Authors' contributions JS, GG and BL conceived the study. GG, JS and KJ collected the data and GG and KJ performed the analyses. $\mathrm{KJ}$ wrote the first draft and all authors contributed to interpretation and writing.

Funding Open access funding provided by Swedish University of Agricultural Sciences. This work was supported by FORMAS (grant no 217-2012-546), the Swedish Research Council (VR) (project no 2015-04882), Vinnova (grant no 2019-03167) and the Swedish Infrastructure of Ecosystem Science (SITES) sponsored by the VR.

Data availability Data supporting this article are available through Zenodo: https://doi.org/10.5281/zenodo.4971647

Code availability Code to reproduce the analyses is avaibable through Zenodo: https://doi.org/10.5281/zenodo.4971647

\section{Declarations}

Competing interests The authors declare no competing interests.

Open Access This article is licensed under a Creative Commons Attribution 4.0 International License, which permits use, sharing, adaptation, distribution and reproduction in any medium or format, as long as you give appropriate credit to the original author(s) and the source, provide a link to the Creative Commons licence, and indicate if changes were made. The images or other third party material in this article are included in the article's Creative Commons licence, unless indicated otherwise in a credit line to the material. If material is not included in the article's Creative Commons licence and your intended use is not permitted by statutory regulation or exceeds the permitted use, you will need to obtain permission directly from the copyright holder. To view a copy of this licence, visit http://creativecommons.org/licenses/by/4.0/.

\section{References}

Aber JD, Nadelhoffer KJ, Steudler P, Melillo JM (1989) Nitrogen Saturation in Northern Forest Ecosystems. Bioscience 39:378-386. https://doi.org/10.2307/1311067

Allison SD, Hanson CA, Treseder KK (2007) Nitrogen fertilization reduces diversity and alters community structure of active fungi in boreal ecosystems. Soil Biol Biochem 9:1878-1887. https://doi.org/10.1016/j.soilbio.2007.02. 001

Baskaran P, Hyvönen R, Berglund SL, Clemmensen KE, Ågren GI, Lindahl BD et al (2017) Modelling the influence of ectomycorrhizal decomposition on plant nutrition and soil carbon sequestration in boreal forest ecosystems. New Phytol 213:1452-1465. https://doi.org/10.1111/nph.14213

Bastin J-F, Finegold Y, Garcia C, Mollicone D, Rezende M, Routh D et al (2019) The global tree restoration potential. 
Science 365:76-79. https://doi.org/10.1126/science. aax0848

Bates D, Mächler M, Bolker B, Walker S. (2015) Fitting Linear Mixed-Effects Models Using lme4. J. Stat. Softw 67:148. https://doi.org/10.18637/jss.v067.i01

Baul TK, Alam A, Ikonen A, Strandman H, Asikainen A, Peltola $\mathrm{H}$ et al (2017) Climate Change Mitigation Potential in Boreal Forests: Impacts of Management, Harvest Intensity and Use of Forest Biomass to Substitute Fossil Resources. Forests 8:455. https://doi.org/10.3390/f8110455

Berg B, McClaugherty C (2014) Plant Litter Decomposition, Humus Formation, Carbon Sequestration, 3rd edn. Springer, Berlin Heidelberg

Bergh J, Nilsson U, Allen HL, Johansson U, Fahlvik N (2014) Long-term responses of Scots pine and Norway spruce stands in Sweden to repeated fertilization and thinning. For Ecol Manag 320:118-128. https://doi.org/10.1016/j. foreco.2014.02.016

Binkley D, Högberg P (2016) Tamm Review: Revisiting the influence of nitrogen deposition on Swedish forests. For Ecol Manag 368:222-239. https://doi.org/10.1016/j. foreco.2016.02.035

Bödeker ITM, Clemmensen KE, de Boer W, Martin F, Olson Å, Lindahl BD (2014) Ectomycorrhizal Cortinarius species participate in enzymatic oxidation of humus in northern forest ecosystems. New Phytol 203:245-256. https:// doi.org/10.1111/nph.12791

Braun S, Thomas VFD, Quiring R, Flückiger W (2010) Does nitrogen deposition increase forest production? The Role of Phosphorus Environ Pollut 158:2043-2052. https://doi. org/10.1016/j.envpol.2009.11.030

Bravo-Oviedo A, Ruiz-Peinado R, Modrego P, Alonso R, Montero G (2015) Forest thinning impact on carbon stock and soil condition in Southern European populations of P. sylvestris L. For Ecol Manag 357:259-267. https://doi. org/10.1016/j.foreco.2015.08.005

Canadell JG, Raupach MR (2008) Managing forests for climate change mitigation. Science 320:1456-1457. https://doi. org/10.1126/science. 1155458

Clemmensen KE, Bahr A, Ovaskainen O, Dahlberg A, Ekblad A, Wallander $\mathrm{H}$ et al (2013) Roots and associated fungi drive long-term carbon sequestration in Boreal forest. Science 339:1615-1618. https://doi.org/10.1126/science. 1231923

Davidson EA, Belk E, Boone RD (1998) Soil water content and temperature as independent or confounded factors controlling soil respiration in a temperate mixed hardwood forest. Glob Change Biol 4:217-227. https://doi.org/10.1046/j. 1365-2486.1998.00128.x

DeLuca TH, Boisvenue C (2012) Boreal forest soil carbon: distribution, function and modelling. Forestry 85:161-184. https://doi.org/10.1093/forestry/cps003

de Vries W, Solberg S, Dobbertin M, Sterba H, Laubhann D, van Oijen $M$ et al (2009) The impact of nitrogen deposition on carbon sequestration by European forests and heathlands. For Ecol Manag 258:1814-1823. https://doi. org/10.1016/j.foreco.2009.02.034

Entwistle EM, Romanowicz KJ, Argiroff WA, Freedman ZB, Morris JJ, Zak DR (2018) Anthropogenic $\mathrm{N}$ deposition alters the composition of expressed class II fungal peroxidases. Appl Env Microbiol 84:e02816-e2817. https://doi.org/10.1128/AEM.02816-17

Entwistle EM, Zak DR, Argiroff WA (2017) Anthropogenic N deposition increases soil $\mathrm{C}$ storage by reducing the relative abundance of lignolytic fungi. Ecol Monogr 88:225244. https://doi.org/10.1002/ecm.1288

Forsmark B, Wallander H, Nordin A, Gundale MJ (2020) Long-term nitrogen enrichment does not increase microbial phosphorus mobilization in a northern coniferous forest. Funct Ecol 35:277-287. https://doi.org/10.1111/13652435.13701

Forstner SJ, Wechselberger V, Stecher S, Müller S, Keiblinger KM, Wanek W, et al. (2019) Resistant Soil Microbial Communities Show Signs of Increasing Phosphorus Limitation in Two Temperate Forests After Long-Term Nitrogen Addition. Front. For. Glob. Change 2(73). https://doi. org/10.3389/ffgc.2019.00073

Frey SD (2019) Mycorrhizal Fungi as Mediators of Soil Organic Matter Dynamics. Annu Rev Ecol Evol Syst 50:237-259. https://doi.org/10.1146/annurev-ecols ys-110617-062331

Gauthier S, Bernier P, Kuuluvainen T, Shvidenko AZ, Schepaschenko DG (2015) Boreal forest health and global change. Science 349:819-822. https://doi.org/10.1126/science. aaa9092

Griscom BW, Adams J, Ellis PW, Houghton RA, Lomax G, Miteva DA et al (2017) Natural climate solutions. Proc Natl Acad Sci 114:11645-11650. https://doi.org/10.1073/ pnas.1710465114

Högberg MN, Briones MJI, Keel SG, Metcalfe DB, Campbell C, Midwood AJ et al (2010) Quantification of effects of season and nitrogen supply on tree below-ground carbon transfer to ectomycorrhizal fungi and other soil organisms in a boreal pine forest. New Phytol 187:485-493. https:// doi.org/10.1111/j.1469-8137.2010.03274.x

Högberg P, Näsholm T, Franklin O, Högberg MN (2017) Tamm Review: On the nature of the nitrogen limitation to plant growth in Fennoscandian boreal forests. For Ecol Manag 403:161-185. https://doi.org/10.1016/j.foreco. 2017.04.045

Honaker J, King G, Blackwell M (2011) Amelia II: A program for missing data. J Stat Softw 45:1-47. https://doi.org/10. 18637/jss.v045.i07

Hyvönen R, Persson T, Andersson S, Olsson B, Ågren GI, Linder S (2008) Impact of long-term nitrogen addition on carbon stocks in trees and soils in northern Europe. Biogeochemistry 89:121-137. https://doi.org/10.1007/ s10533-007-9121-3

Intergovernmental Panel on Climate Change (IPCC). (2018) An IPCC Special Report on the Impacts of Global Warming of $1.5{ }^{\circ} \mathrm{C}$ Above Pre-industrial Levels and Related Global Greenhouse Gas Emission Pathwys.

Intergovernmental Panel on Climate Change (IPCC). (2006) 2006 IPCC Guidelines for National Greenhouse Gas Inventories, Volume 4 Agriculture, Forestry and Other Land Use. Available: https://www.ipcc-nggip.iges.or.jp/ public/2006gl/vol4.html

James J, Harrison R (2016) The Effect of Harvest on Forest Soil Carbon: A Meta-Analysis. Forests 7:308. https://doi. org/10.3390/f7120308 
Janssens IA, Dieleman W, Luyssaert S, Subke J-A, Reichstein M, Ceulemans R et al (2010) Reduction of forest soil respiration in response to nitrogen deposition. Nat Geosci 3:315-322. https://doi.org/10.1038/ngeo844

Jansson PE (1987) Simulated soil temperature and moisture at a clearcutting in central Sweden. Scand J for Res 2:127140. https://doi.org/10.1080/02827588709382452

Kjønaas OJ, Wright RF (2007) Use of ${ }^{15} \mathrm{~N}$-labelled nitrogen deposition to quantify the source of nitrogen in runoff at a coniferous-forested catchment at Gårdsjön, Sweden. Environ Pollut 147:791-799. https://doi.org/10.1016/j.envpol. 2006.06.019

Kutzbach L, Schneider J, Sachs T, Giebels M, Nykänen H, Shurpali NJ et al (2007) $\mathrm{CO}_{2}$ flux determination by closed-chamber methods can be seriously biased by inappropriate application of linear regression. Biogeosciences 4:1005-1025. https://doi.org/10.5194/bg-4-1005-2007

Kyaschenko J, Clemmensen KE, Hagenbo A, Karltun E, Lindahl BD (2017a) Shift in fungal communities and associated enzyme activities along an age gradient of managed Pinus sylvestris stands. ISME J 11:863-874. https://doi. org/10.1038/ismej.2016.184

Kyaschenko J, Clemmensen KE, Karltun E, Lindahl BD (2017b) Below-ground organic matter accumulation along a boreal forest fertility gradient relates to guild interaction within fungal communities. Ecol Lett 20:1546-1555. https://doi.org/10.1111/ele.12862

Kyaschenko J, Ovaskainen O, Ekblad A, Hagenbo A, Karltun E, Clemmensen KE, Lindahl BD (2019) Soil fertility in boreal forest relates to root-driven nitrogen retention and carbon sequestration in the mor layer. New Phytol 221:1492-1502. https://doi.org/10.1111/nph.15454

Laasasenaho J (1982) Taper curve and volume functions for pine, spruce and birch. Communicationes Instituti Forestalis Fenniae 838. ISBN: 951-40-0589-9

Lajtha K, Bowden RD, Crow S, Fekete I, Kotroczó Z, Plante A et al (2018) The detrital input and removal treatment (DIRT) network: Insights into soil carbon stabilization. Sci Total Environ 640-641:1112-1120. https://doi.org/10. 1016/j.scitotenv.2018.05.388

Lilleskov EA, Fahey TJ, Horton TR, Lovett GM (2002) Belowground ectomycorrhizal fungal community change over a nitrogen deposition gradient in Alaska. Ecology 83:104115. https://doi.org/10.1890/0012-9658(2002)083[0104: BEFCCO]2.0.CO;2

Lindahl BD, Tunlid A (2015) Ectomycorrhizal fungi - potential organic matter decomposers, yet not saprotrophs. New Phytol 205:1443-1447. https://doi.org/10.1111/nph.13201

Lüdecke D (2018) sjPlot - Data Visualization for Statistics in Social Science. https://doi.org/10.5281/zenodo.2400856

Lundmark T, Bergh J, Hofer P et al (2014) Potential roles of Swedish forestry in the context of climate change mitigation. Forests 5:557-578. https://doi.org/10.3390/f5040557

Maaroufi NI, Nordin A, Hasselquist NJ, Bach LH, Palmqvist K, Gundale MJ (2015) Anthropogenic nitrogen deposition enhances carbon sequestration in boreal soils. Glob Change Biol 21:3169-3180. https://doi.org/10.1111/gcb. 12904

Maaroufi NI, Nordin A, Palmqvist K, Hasselquist NJ, Forsmark B, Rosenstock NP et al (2019) Anthropogenic nitrogen enrichment enhances soil carbon accumulation by impacting saprotrophs rather than ectomycorrhizal fungal activity. Glob Change Biol 25:2900-2914. https://doi.org/ 10.1111/gcb.14722

Magnani F, Mencuccini M, Borghetti M, Berbigier P, Berninger F, Delzon S et al (2007) The human footprint in the carbon cycle of temperate and boreal forests. Nature 447:848-850. https://doi.org/10.1038/nature05847

Mäkinen H, Isomäki A (2004) (2004) Thinning intensity and growth of Scots pine stands in Finland. For Ecol Manag 201:311-325. https://doi.org/10.1016/j.foreco.2004.07. 016

Marklund LG (1988) Biomassafunktioner för tall, gran och björk i Sverige : Biomass functions for pine, spruce and birch in Sweden . Rapport/Sveriges Lantbruksuniversitet, Institutionen för skogstaxering, 0348-0496;45, Umeå

Mayer M, Prescott CE, Abaker WEA, Augusto L, Cécillon L, Ferreira GWD et al (2020) Tamm review: influence of forest management activities on soil organic carbon stocks: A knowledge synthesis. For Ecol Manag 466:118127. https://doi.org/10.1016/j.foreco.2020.118127

Moldan F, Kjønaas OJ, Stuanes AO, Wright RF (2006) Increased nitrogen in runoff and soil following 13 years of experimentally increased nitrogen deposition to a coniferous-forested catchment at Gårdsjön. Sweden Environ Pollut 144:610-620. https://doi.org/10.1016/j.envpol.2006. 01.041

Näsholm T, Högberg P, Franklin O, Metcalfe D, Keel SG, Campbell C et al (2013) Are ectomycorrhizal fungi alleviating or aggravating nitrogen limitation of tree growth in boreal forests? New Phytol 198:214-221. https://doi.org/ 10.1111/nph.12139

Nave LE, Vance ED, Swanston CW, Curtis PS (2010) Harvest impacts on soil carbon storage in temperate forests. For Ecol Manag 2595:857-866. https://doi.org/10.1016/j. foreco.2009.12.009

Neumann M, Moreno A, Mues V, Härkönen S, Mura M, Bouriaud $\mathrm{O}$ et al (2016) Comparison of carbon estimation methods for European forests. For Ecol Manag 361:397420. https://doi.org/10.1016/j.foreco.2015.11.016

Nilsson P, Cory N, Stendahl J (2017) Skogsdata 2017. Available from: https://pub.epsilon.slu.se/14487

Nilsson U, Agestam E, Ekö P-M, Elfving B, Fahlvik N, Johansson U, Karlsson K \& Lundmark T (2010) Thinning of Scots pine and Norway spruce monocultures in Sweden: effects of different thinning programmes on stand level gross- and net stem volume production. Studia Forestalia Suecica 209. ISBN: 9789186197766

Palmqvist K, Nordin A, Giesler R (2020) Contrasting Effects of Long-Term Nitrogen Deposition on Plant Phosphorus in a Northern Boreal Forest. Front. For. Glob. Change 3(65). https://doi.org/10.3389/ffgc.2020.00065

Pan Y, Birdsey RA, Fang J, Houghton R, Kauppi PE, Kurz WA et al (2011) A large and persistent carbon sink in the world's forests. Science 333:988-993. https://doi.org/10. 1126/science. 1201609

Petersson H, Ståhl G (2006) Functions for below-ground biomass of Pinus sylvestris, Picea abies, Betula pendula and Betula pubescens in Sweden. Scand J for Res 21:84-93. https://doi.org/10.1080/14004080500486864

Powers M, Kolka R, Palik B, McDonald R, Jurgensen M (2011) Long-term management impacts on carbon storage 
in Lake States forests. For Ecol Manag 262:424-431. https://doi.org/10.1016/j.foreco.2011.04.008

R Core Team. (2018) R: A language and environment for statistical computing. Vienna, Austria: R Foundation for Statistical Computing. Available from: https://www.R-proje ct.org/

Ring ER, Jacobson SJ, Högbom LH (2011) Long-term effects of nitrogen fertilization on soil chemistry in three Scots pine stands in Sweden. Can J for Res 41:289-299. https:// doi.org/10.1139/X10-208

Royal Swedish Academy of Agriculture and Forestry. (2015) Forests and forestry in Sweden. Royal Swedish Academy of Agriculture and Forestry, Stockholm, Sweden. Available: https://www.ksla.se/pdf-meta/?pdf_id=17761\&categ ory=publikationer

Rumpel C, Kögel-Knabner I, Bruhn F (2002) Vertical distribution, age, and chemical composition of organic carbon in two forest soils of different pedogenesis. Org Geochem 33:1131-1142. https://doi.org/10.1016/S0146-6380(02) 00088-8

Schulze K, Borken W, Muhr J, Matzner E (2009) Stock, turnover time and accumulation of organic matter in bulk and density fractions of a Podzol soil. Eur J Soil Sci 60:567577. https://doi.org/10.1111/j.1365-2389.2009.01134.x

Seidl R, Rammer W, Jäger D, Currie WS, Lexer MJ (2007) Assessing trade-offs between carbon sequestration and timber production within a framework of multi-purpose forestry in Austria. For Ecol Manag 248:64-79. https:// doi.org/10.1016/j.foreco.2007.02.035

Skowrońska M, Filipek T (2014) Life cycle assessment of fertilizers: a review. Int Agrophysics 28:101-110. https://doi. org/10.2478/intag-2013-0032

Steidinger BS, Crowther TW, Liang J, Van Nuland ME, Werner GDA, Reich PB et al (2019) Climatic controls of decomposition drive the global biogeography of foresttree symbioses. Nature 569:404-408. https://doi.org/10. 1038/s41586-019-1128-0

Stendahl J, Berg B, Lindahl BD (2017) Manganese availability is negatively associated with carbon storage in northern coniferous forest humus layers. Sci Rep 7:15487. https:// doi.org/10.1038/s41598-017-15801-y

Sterkenburg E, Clemmensen KE, Ekblad A, Finlay RD, Lindahl BD (2018) Contrasting effects of ectomycorrhizal fungi on early and late stage decomposition in a boreal forest. Isme J 12:2187-2197. https://doi.org/10.1038/ s41396-018-0181-2

Strengbom J, Axelsson EP, Lundmark T, Nordin A (2018) Trade-offs in the multi-use potential of managed boreal forests. J Appl Ecol 55:958-966. https://doi.org/10.1111/ 1365-2664.13019

Strengbom J, Dahlberg A, Larsson A, Lindelöw Å, Sandström J, Widenfalk $O$ et al (2011) Introducing intensively managed spruce plantations in Swedish forest landscapes will impair biodiversity decline. Forests 2:610-630. https:// doi.org/10.3390/f2030610
Strengbom J, Nordin A (2008) Commercial forest fertilization causes long-term residual effects in ground vegetation of boreal forests. For Ecol Manag 256:2175-2181. https:// doi.org/10.1016/j.foreco.2008.08.009

Swift MJ, Heal OW, Anderson JM, Anderson JM (1979) Decomposition in terrestrial ecosystems. Blackwell, Oxford

Tamm CO (1991) Nitrogen in Terrestrial Ecosystems: Questions of Productivity, Vegetational Changes, and Ecosystem Stability. Springer-Verlag, Berlin Heidelberg

Terrer C, Phillips BA, Rosende J, Pett-Ridge J, Craig ME, van Groenigen KJ et al (2021) A trade-off between plant and soil carbon storage under elevated $\mathrm{CO}_{2}$. Nature 591:599603. https://doi.org/10.1038/s41586-021-03306-8

Tipping E, Davies JAC, Henrys PA, Kirk GJD, Lilly A, Dragosits U et al (2017) Long-term increases in soil carbon due to ecosystem fertilization by atmospheric nitrogen deposition demonstrated by regional-scale modelling and observations. Sci Rep 7:1890. https://doi.org/10.1038/ s41598-017-02002-w

Valinger E, Elfving B, Mörling T (2000) Twelve-year growth response of Scots pine to thinning and nitrogen fertilisation. For Ecol Manag 134:45-53. https://doi.org/10.1016/ S0378-1127(99)00244-3

Van Sundert K, Horemans JA, Stendahl J, Vicca S (2018) The influence of soil properties and nutrients on conifer forest growth in Sweden, and the first steps in developing a nutrient availability metric. Biogeosciences 15:34753496. https://doi.org/10.5194/bg-15-3475-2018

Vitousek PM, Howarth RW (1991) Nitrogen limitation on land and in the sea: How can it occur? Biogeochemistry 13:87115. https://doi.org/10.1007/BF00002772

Westoby (1984) M. The self-thinning rule. Adv Ecol Res 14:167-225. https://doi.org/10.1016/S0065-2504(08) 60171-3

Widdig M, Schleuss P-M, Weig AR, Guhr A, Biederman LA, Borer ET, et al. (2019) Nitrogen and phosphorus additions alter the abundance of phosphorus-solubilizing bacteria and phosphatase activity in grassland soils. Front Environ Sci 7(185). https://doi.org/10.3389/fenvs.2019.00185

Zak DR, Holmes WE, Burton AJ, Pregitzer KS, Talhelm AF (2008) Simulated Atmospheric NO3- Deposition Increases Soil Organic Matter by Slowing Decomposition. Ecol Appl 18:2016-2027. https://doi.org/10.1890/ $07-1743.1$

Zhang X, Guan D, Li W, Sun D, Jin C, Yuan F et al (2018) The effects of forest thinning on soil carbon stocks and dynamics: A meta-analysis. For Ecol Manag 429:36-43. https:// doi.org/10.1016/j.foreco.2018.06.027

Publisher's note Springer Nature remains neutral with regard to jurisdictional claims in published maps and institutional affiliations. 